\title{
Outdoor education in historical perspective
}

\section{Mark Freeman and Jayson Seaman}

This special issue of History of Education Review, focused on "Outdoor Education in Historical Perspective", presents a number of articles that advance nuanced and contextualized representations of outdoor education as a sub-field that cuts across formal and informal settings. The contributors include historians of education, and practitioners of outdoor education who have found a historical approach helpful in shaping their understanding of the field. As with many other areas of historical research, especially but not solely in the history of education, much of the existing scholarship on outdoor education is characterized by practitioner research that takes a historical turn (see for example Seaman, Brown and Quay, 2017). This can be helpful in finding support for new or existing practices, and the approach is also used to build affinity for specific institutions and to socialize readers into particular worldviews associated with outdoor education (see the epilogue in Kliebard, 1995). Although such an approach carries the danger of using history in a narrowly instrumental way that can occlude criticality, it has stimulated a lot of worthwhile research that has illuminated contemporary understandings of 'experiential education' in both theory and practice. Some outdoor educators, at least, are closely in touch with the history of their own field.

There is, however, a fairly modest historical literature on outdoor education (though for a recent significant example see Ogilvie, 2013); it has not been a significant feature of the history of education. It sometimes falls between two substantial areas of scholarship: the history of landscape and the "outdoors" on the one hand, and the history of organised youth movements, such as the Scouts and Guides, on the other. In Britain in particular, a strong body of literature on the relationship between landscapes and national identity (for a recent example see Readman, 2018) has emphasised the strong and longstanding cultural power of exploring outdoor landscapes. (A parallel literature examines Britain and the sea (for a survey, see O'Hara, 2010): the sea, of course, has also played an important role in national self-identity and indeed - as the case of the Aberdovey Sea School, examined in Mark Freeman's contribution to this special issue, demonstrates - the history of outdoor education.) Walking, climbing and even trespassing have played a significant role in the cultural politics of twentieth-century Britain (Taylor, 1997). The American landscape, too, has a richly explored political and cultural history, similarly characterized by struggles over access, which have had - among other things - a powerfully racialized dimension (Outka, 2008; Finney, 2014). Meanwhile, a whole range of historians have explored the institutional and cultural histories of Scouting, Guiding and other youth movements across the world, placing them in the contexts of nationalism, militarism, youth politics and, in some cases, formal education too (for one recent example, focusing on the English countryside, see Edwards, 2018). Key studies of "muscular Christianity", focusing particularly on nineteenthand twentieth-century Britain and America (see, especially, Putney, 2001), have brought some of these themes together, and some scholars have emphasised the ongoing relevance of the ideologies of muscular Christianity in some areas of contemporary educational ideas and practice (see, for example, MacAloon, 2006). Yet “outdoor education", specifically, is comparatively rarely addressed - a lacuna that this special issue aims, though of course only in part, to fill.

This issue brings outdoor educators and historians of education and youth together to explore aspects of the modern - mostly, the twentieth-century - history of outdoor education. The contexts explored range from Britain to America to Czechoslovakia and the Czech Republic, 
and from universities to youth organisations and individual biography. "Outdoor education" can mean, and has meant, many things. The "outdoors", as Sian Edwards's article reminds is, may often be rural, but has also, for some of those engaged in outdoor education, been urban. Her case study, of the Girl Guides and urban outdoor exploring, shows the productive potential of considering well-known informal education organisations in new ways, through a specific focus on the "outdoors". Each article in the special issue can be read and understood individually. However, a few themes are discernible from this and other work on the history of outdoor education, which are briefly reviewed in this introduction. The themes cannot be easily separated - "religion" and "personality", in particular, have become deeply intertwined over the past century (Susman, 1979; Warren, 1998) - but these categories may be useful to the reader in both charting a path through the contributions to this issue and in identifying opportunities for further research into the history of outdoor education.

\section{Transculturality}

Outdoor education focused on character, rather than environmentalism or other formal subjects, is typically associated with the German educator Kurt Hahn, who appears as a significant individual or influence in several of the papers in this special issue. Hahn's best-known legacy organization is Outward Bound, which began in Wales in 1941 and then expanded globally in the 1950s and 1960s. Outdoor education in the Hahnian mold has therefore always been transcultural - although its influence typically flowed in one direction as a colonial or assimilationist enterprise.

Nonetheless, there existed some correspondence between the values and aims of Outward Bound's exponents and those in various locales, as two articles in particular show: one by Jayson Seaman, Robert MacArthur and Sean Harrington, and one by Andy Martin, Geoff Watson, Jan Neuman, Ivana Turčová and Lucie Kalcusová. Seaman et al. argue that Outward Bound initially migrated to the United States amidst the religiosity, masculinity and internationalism that defined the early Cold War period. In the U.S., its original status as a residentially-based "training holiday" program (Taylor, 1997) in Britain quickly transformed into a "mobile" (James, 1980) course operation involving extended excursions into wilderness and waterway areas. The organization's Christian foundation yielded first to a new motif of frontier masculinity, and then, quickly, to a secular focus on group dynamics and the self, a central element in the human potential movement, whose ideas and practices Outward Bound incorporated when it adopted the language of "experiential education" in the late 1960s and early 1970s. This change was essential to the "mainstreaming" agenda Outward Bound launched in 1968, which Dartmouth College influenced. The article by Seaman et al. illustrates how transcultural migration is likely accompanied by ideological shifts that deserve close historical study.

Martin et al. discuss the way outdoor education evolved in the Czech Republic, identifying three main Czech traditions: turistika, sokol and Junák. These different forms of outdoor education, they argue, were important to maintaining social solidarity and some degree of individual freedom throughout the long Czech history of political repression, even affording opportunities for some - namely Olympic-level athletes skilled in outdoor disciplines - to escape the communist regime in the 1950s and 1960s. Martin et al. (p. 3) write:

Clearly, there was a duality - sport was propaganda for the system, societal achievement and ideologically accepted. There was significant state support for sport, from the local to 
national level. However, this popularity also enabled Czechs to escape the regime through sport, but also allowed going into nature through participation in outdoor sports such as cycling, skiing, and canoeing/kayaking.

The Czech example illustrates how outdoor education anywhere is likely to represent a mixture of indigenous and imported influences, adapted to the cultural and political environment of its specific location, and propagated through official channels like institutions of higher education. Future comparative research such as that by Søren Ankjær (2012) will help trace influences like the ones laid out here.

In terms of transculturality, it has been difficult, historiographically speaking, to assess how the peculiarity of various national conditions may have aided, thwarted, or otherwise shaped outdoor educators' ambitions. There is simply not enough work on the topic. The articles contained in this issue provide some limited clues, but further research certainly is warranted. For example, in the 1950s Outward Bound expanded into Africa and east Asia. To what extent were these projects an artifact of colonialism or a tool for its expurgation? Situating outdoor education in the historical context of specific locations is therefore essential to contemporary transcultural efforts.

\section{Space and place}

The histories attached to outdoor spaces and places figure prominently in recent efforts to draw attention to their racialized and politicized dimensions (Readman, 2018; Finney, 2014; Outka, 2008; Savoy, 2016). These accounts draw important attention to the gaps created by Romantic views of nature as neutral and innocent. Apart from this recent turn, histories focusing on outdoor space and place are limited (but see Higgins, 2002; Lynch and Moore, 2004; Newbery, 2012; Stewart, 2008). In the present issue, Edwards's article on Girl Guides contributes to this important literature. Edwards illustrates how Girl Guides construed urban spaces as sites of citizenship training through the merger of Guiding practices and everyday activities. This work suggests that the boundaries between "formal" and "informal", and between "organized" and "unstructured" youth activities, have been, and probably remain, highly permeable. Edwards's argument suggests that the ideological work done by outdoor education organizations functions in part through the management of space (see also Van Slyck, 2010) and the corresponding associations with nature - or other places. As Edwards writes:

Nature observation was thus constructed as being an almost active part of the everyday life of Guides, supporting the notion that Guiding was a "way of being" rather than an extra-curricular activity. Guides were expected to apply "noticing eyes" in their daily routines, and to the buildings, streets and parks around them. (p. 16).

Edwards challenges historians and contemporary educators alike to recognize the ideological work that "outdoor education" has done even in the more constrained outdoor spaces of urban England. In many ways, this is the point of the entire enterprise of outdoor education - to shape young people's outlook and conduct when not in the "great outdoors", or indeed not outdoors at all. Outward Bound courses, for example, were intended - probably implausibly - to shape the subsequent careers of those who would have responsibility for industrial leadership, for many decades after their brief exposure to the outdoor activities that formed part of the "training" (see 
Freeman, 2011). Importantly, Edwards further reminds us that the psychological contours of such experiences were, and probably still are, gendered (see also Miranda, 1991)

This work belies the seemingly unproblematic "naturalness" of the outdoors and outdoor organizations, and suggests that the leading focus for scholars should be on the significance given to different spaces and places in various ideological configurations, as they are promoted by youth organizations.

\section{Religion and spirituality}

An approach to understanding why outdoor education often occurs in "grand" locations is to examine how their meaning is refracted through the spiritual significance such spaces are presumed to have. At various times religion has played a more or less significant role in structuring these meanings. Today, it is commonplace to understand nature as a "spiritual" place, but only recently its spiritual significance was more directly harnessed to institutional purposes. Outward Bound's Christian origins form the explicit focus of Mark Freeman's article in this special issue. Freeman extends his earlier work (2011) on Outward Bound's shift from "character training" to "personal growth," another example of the ideological displacement that occurred throughout the organization in the 1960s. Here Freeman examines the extent to which explicit Christian principles animated Outward Bound's model of character training and appeared in its courses as religious observances and practices. Christianity played a central (though not long uncontested) role in defining Outward Bound's original organizational culture, yet this aspect of the movement has received scant attention. Freeman's article corrects this omission and also adds an important dimension to understanding how the relationship between nature and a more widely palatable idea of spirituality gained wider currency in the 1960s. As Seaman et al. also show, these ideas were circulating in the U.S. in the early 1960s, too, although the American version of Outward Bound that found expression at Dartmouth lacked the formal Christian component that had characterized the earlier British foundations.

Religion as a focal object is more implied than explicit in the article by Mark Leather, Gil Fewings and Su Porter's on the "Romantic origins at the University of St Mark and St John", which evidences a strong sense of mission in efforts to expand access to higher education in the mid-nineteenth century. Leather et al. (p. 7) write: "The Romantic form of mountaineering was not motivated by the prospect of new scientific knowledge, rather by an embodied, visceral and 'quasimystical' relationship of the poets with mountains". The concept of mountaineering, coined by Samuel Taylor Coleridge, expressed a new sentiment toward the mountains: that they might be ascended for pleasure rather than scientific enquiry. "Mountains", as Robert Macfarlane (2003) has written, clearly became "of the mind", a place for traversing the contours of one's "interior geography” as much as a physical destination. St Marks and St John's Colleges - now the University of St Mark and St John, or simply "Marjon" - harnessed these new conceptions to undergird their founders' missions to broaden access to higher education, with the outdoors playing a central part in the University programme.

Religion has played only a minor role in the historiography of outdoor education, but these articles suggest that it deserves greater attention in the future. Even the more secular "spirituality" cannot be taken for granted as a natural phenomenon, but is itself derived from historical processes and struggles, as Freeman shows. Untangling the relationships between religion, spirituality and nature as they have been propagated in different outdoor education sites will be a fruitful effort in the future. 


\section{Personality - and personalities}

Arguably the writing of history in outdoor education has been dominated by a preoccupation with personality. The heavy shadow cast by Kurt Hahn, over the historiography of outdoor education in general and over many of the articles in this special issue, is an example of this. There is a large, often hagiographical, literature on Hahn, and many of those organisations with which he was associated - examples include Gordonstoun and Outward Bound International emphasise his foundational role in their own historical material. ${ }^{1}$ More critical and historically contextualised studies of Hahn and his influence are available (see, for example, Veevers and Allison, 2011), but there is still no full scholarly biography. Aspects of Hahn's legacy were contested in his own time - as Mark Freeman's article in this issue shows - but there is no doubt that his influence was both deep and wide.

As such, the study of outdoor education - which often takes the idea of "personality" as an important element - can benefit from a closer examination of key personalities. In this issue, Franklin Vernon, in a discussion of Hahn's pedagogy, occupies this terrain as he interrogates the prescriptive use of adventure as an aspect of that pedagogical approach. Personality has a kind of dual valence in Vernon's article: on the one hand, it is possible that adventure represents the prescriptive externalization of repressed tendencies shared among Hahn and some of his compatriots, a view that only becomes clear when he's situated in a particular stratum of the ruling class. On the other hand, the method of prescriptive adventure was explicitly meant to shape his students' personalities in a specific way. "Hahn", Vernon (p. 20, his emphasis) writes, "anticipated two latent capacities that existed in all prepubescent males: homosexuality, and then something of value. The arrival of one meant the death of the other." A more detailed biography would help elucidate the first of these "latent capacities" in Hahn, and further research that scrutinizes Vernon's argument through the use of primary source materials would further substantiate the second.

This special issue, then, surveys the role of key personalities - and not just that of Hahn. It also contains a good dose of institutional history: the Outward Bound school at Eskdale (Freeman), Dartmouth College (Seaman et al.) and Marjon (Leather et al.) are all the subject of detailed case studies. Indeed, the authors of these articles are arguably engaged in writing institutional "biographies", and it is acknowledged that this approach may not always be the best way to generate critical perspectives on outdoor education. Recent work in the history of education has shifted away from an institutional approach, and many have welcomed this (see, for example, Woodin, 2007, p. 491). However, so much outdoor education took place within institutions such as these that it would be difficult, if not impossible, to write them out of the picture. Indeed, it could be argued that the institutions themselves had "personalities" that exercised (or tried to exercise) an influence over the "character" or "personality" of those who attended them. Moving beyond these case studies, however, or conducting comparative research, is necessary to offset the dangers of focusing too heavily on potentially unrepresentative institutions of outdoor education. It is important to disrupt institutional "foundation myths" (Brookes, 2016) that decontextualize otherwise rich and important historical processes, and thus to place institutions, and "personalities" such as Hahn, into their historical contexts.

For outdoor educators, the project ahead is to further develop a contextualized history of ideas and practice that makes fuller links with wider historical, social and educational developments. One feature of this project should also be to seek representation of diverse 
scholars and subjects; the present collection represents the limitations of a relatively homogeneous pool of candidates in terms of gender, race, class and cultural context (cf. Humberstone and Brown, 2006). For historians of education, a wider and more thorough examination of the "outdoor" can add depth and breadth to existing avenues of inquiry in the sub-discipline. The rapid and ongoing globalisation of the scope of English-language research in the history of education (see Freeman and Kirke, 2017) offers some potential here to diversify the range and authorship of research in the history of outdoor education. There is also considerable scope for careful historical exploration of the boundaries of "outdoor education". Sitting as it does at the intersection of leisure, formal schooling, youth and social movements and environmental activism, outdoor education offers scope for productive engagement with many other areas of historical research.

1 'Gordonstoun: Our History', https://gordonstoun.org.uk/our-history; 'Outward Bound International: About Us', https://www.outwardbound.net/about-us/ (both accessed 16 April 2020). 


\section{References}

Ankjær, S. (2012), "A cultural and comparative perspective on outdoor education in New Zealand and friluftsliv in Denmark", Journal of Adventure Education and Outdoor Learning, Vol. 12, No. 2, pp. 121-36.

Brookes, A. (2016), "Foundation myths and the roots of adventure education in the Anglosphere", in B. Humberstone, H. Prince and K. A. Henderson (Eds), Routledge International Handbook of Outdoor Studies, London: Routledge, pp. 11-19.

Edwards, S. (2018), Youth Movements, Citizenship and the English Countryside: Creating Good Citizens 1930-1960, Basingstoke: Palgrave Macmillan.

Finney, C. (2014), Black Faces, White Spaces: Reimagining the Relationship of African Americans to the Great Outdoors, Chapel Hill, N. C.: University of North Carolina Press.

Freeman, M. (2011) "From 'character-training' to 'personal growth': the early history of Outward Bound 1941-1965”, History of Education, Vol. 40 No. 1, pp. 21-43.

Freeman, M. and Kirke, A. (2017), "Review of periodical literature on the history of education published in 2016', History of Education, Vol. 46, No. 6, pp. 826-53.

Higgins, P. (2002), "Outdoor education in Scotland", Journal of Adventure Education and Outdoor Learning, Vol. 2, No. 2, pp. 149-68.

Humberstone, B. and Brown, H. (Eds) (2006), Shaping the Outdoor Profession through Higher Education: Creative Diversity in Outdoor Studies Courses in Higher Education in the $U K$, Carlisle: Institute for Outdoor Learning.

James, T. (1980), Service - What Is It, and Why?, unpublished paper.

Kliebard, H. M. (1995), The Struggle for the American Curriculum 1893-1958, 2nd ed., New York: Routledge.

Lynch, P. and Moore, K. (2004), "Adventures in paradox", Australian Journal of Outdoor Education, Vol. 8, No. 2, pp. 3-12.

MacAloon, J. J. (2006), "Introduction: muscular Christianity after 150 years", International Journal of the History of Sport, Vol. 23, No. 5, pp. 687-700.

Macfarlane, R. (2003), Mountains of the Mind, New York: Pantheon Books.

Miranda, W. (1991), "Gender based educational politics: the case of the Camp Directors Association, 1924-1932", Journal of Thought, Vol. 26, No. 1/2, pp. 45-67. 
Newbery, L. (2012), "Canoe pedagogy and colonial history: exploring contested spaces of outdoor environmental education", Canadian Journal of Environmental Education, Vol. 17, pp. 30-45.

Ogilvie, K. (2013), Roots and Wings: A History of Outdoor Education and Outdoor Learning in the UK, Lyme Regis: Russell House Publishing.

O'Hara, G. (2010), Britain and the Sea: Since 1600, Basingstoke: Palgrave Macmillan.

Outka, P. (2008), Race and Nature from Transcendentalism to the Harlem Renaissance, New York: Palgrave MacMillan.

Putney, C. (2001), Muscular Christianity: Manhood and Sports in Protestant America 18801920, Cambridge, Mass.: Harvard University Press.

Readman, P. (2018), Storied Ground: Landscape and the Shaping of English National Identity, Cambridge: Cambridge University Press.

Savoy, L. (2016), Trace: Memory, History, Race, and the American Landscape, Berkeley, Calif.: Counterpoint Press.

Seaman, J., Brown, M. and Quay, J. (2017), "The evolution of experiential learning theory: tracing lines of research in the JEE", Journal of Experiential Education, Vol. 40, No. 4, pp. NP1-NP21.

Stewart, A. (2008), "Whose place, whose history? Outdoor environmental education pedagogy as 'reading' the landscape", Journal of Adventure Education and Outdoor Learning, Vol. 8 No. 2, pp. 79-98.

Susman, W. I. (1979), "Personality and the making of 20th century culture", in J. Higham and P. K. Conkin (Eds), New Directions in American Cultural History, Baltimore, Md.: Johns Hopkins University Press, pp. 212-26.

Taylor, H. (1997), A Claim on the Countryside: A History of the British Outdoor Movement. Keele: Keele University Press.

Van Slyck, A. (2010), A Manufactured Wilderness: Summer Camps and the Shaping of American Youth 1890-1960, Minneapolis, Minn.: University of Minnesota Press.

Veevers, N. and Allison, P. (2011), Kurt Hahn: Inspirational, Visionary, Outdoor and Experiential Educator, Rotterdam: Sense Publishers.

Warren, H. A. (1998), "The shift from character to personality in mainline Protestant thought 1935-1945", Church History, Vol. 67 No. 3, pp. 537-55. 
Woodin, T. (2007). "Working-class education and social change in nineteenth- and twentiethcentury Britain", History of Education, Vol. 36, No. 4/5, pp. 483-96. 